\title{
New Data for an Updated Youth Energy Expenditure Compendium: An Introduction
}

\author{
Stephen D. Herrmann and Karin A. Pfeiffer
}

In 1993, Ainsworth et al published the Compendium of Physical Activities (compendium: https://sites.google.com/site/compendiumofphysicalactivities) to address the issue of how to code physical activities by type and intensity in a standardized system across studies of adults. ${ }^{1}$ It was intended to help investigators collecting physical activity (PA) data by diary, recall, or direct observation describe PA on a common metric of energy expenditure. This metric could be used to characterize patterns of PA in populations, determinants of PA, or relationships between PA and health or disease. Use of such a common metric also could allow comparisons of the results of diverse intervention studies targeting multiple PAs.

Until 2008, many researchers studying children and adolescents relied on the adult compendium to translate PA behaviors into energy expenditure (EE) units. However, it is known that changes in resting metabolic rate and relative energy cost of PAs occur with growth and maturation, ${ }^{2,3}$ making the use of adult-based metabolic equivalent (MET) values inappropriate for youth. In response, Ridley et al developed the Compendium of Energy Expenditures for Youth. ${ }^{4}$ Because more than $60 \%$ of the values included in the youth compendium were adult-based values ${ }^{4}$ and because considerable additional estimates of EE for PA have been published in the past 5 to 10 years, we believed efforts to update the youth compendium would be worthwhile.

\section{Recent Youth Compendium Efforts}

The National Collaborative for Childhood Obesity Research (NCCOR; http://www.nccor.org), a partnership of 4 leading research funders whose mission is to accelerate progress in reducing childhood obesity, recognized the value of extending the existing youth compendium and convened a group of experts in April 2012. The experts discussed the potential impact an updated compendium could make for both researchers and practitioners, and considered potential difficulties associated with obtaining EE values that would be derived from data on youth. The group then began work on 3 main tasks. The first task was to decide on the EE metric that should be used and how much of an impact age-related differences would have on that metric. McMurray et al explored various metrics to minimize the influence of age, physical characteristics, and sex that are potential confounders when measuring EE in youth. ${ }^{5}$ McMurray recommended the Youth-MET as the best metric for

Herrmann (Stephen.Herrmann@SanfordHealth.org) and Pfeiffer (kap@ msu.edu) are Guest Editors for this supplemental issue of the Journal of Physical Activity and Health. Herrmann is with the Children's Health Research Center, Sanford Research, Sioux Falls, SD. Pfeiffer is with the Dept of Kinesiology, Michigan State University, East Lansing, MI. accuracy and practicality. ${ }^{5}$ Since then, the expert group has conducted additional work to account for age-related differences in EE.

The second task was to conduct a comprehensive literature search to find newly published data on measured EE values for youth physical activities. The group is working on conducting this literature search and it is near completion.

The third task was a call for researchers to submit unpublished data on youth EE. This third task has resulted in this supplemental issue, New Data for an Updated Youth Energy Expenditure Compendium, which aims to present additional, previously unpublished data to directly inform the updated youth compendium. Together, all of these activities will contribute to the development of an updated youth energy expenditure compendium.

\section{Highlights of This Issue}

This supplemental issue was commissioned by NCCOR to solicit unpublished data on the EE of children and adolescents performing specific activities. It contains an exciting group of 17 high-quality articles from 4 countries. An important consideration for all studies included in this supplemental issue was the methodology used to assess EE. To be included, studies were required to use some form of indirect calorimetry or whole-room calorimetry to measure EE.

The articles in this supplement are unique in that they span a wide range of ages and contribute previously unavailable EE values across age groups and developmental levels. Three studies evaluate preschool children and contribute EE data for activities pertinent to this age group, such as active video games, ball toss, standing art, cleaning up, treasure hunt, bicycle riding, obstacle course, shooting baskets, and soccer (Byun ${ }^{6}$; Großeck ${ }^{7}$; Puyau ${ }^{8}$ ). Other studies evaluate a large age range, from 5 to 17 or 18 years old ( Lau $^{9}$; Ondrak ${ }^{10} ;$ Sasaki $^{11} ;$ Schuna $\left.^{12}\right)$. One article even examines developmental trajectories of EE values (Trost ${ }^{13}$ ).

Another important contribution of this supplement is that the included studies cover nearly 250 separate activities. One study alone includes 70 activities (Sasaki ${ }^{11}$ ). Others focus on specific activities, such as tennis practice and match play $\left(\right.$ Ondrak $\left.^{10}\right)$, different types of chores $\left(\right.$ Ridley $\left.{ }^{14}\right)$, rollerblading and riding a scooter $\left(\right.$ Ridley $\left.{ }^{14}\right)$, relay races $\left(\right.$ Clevenger $\left.{ }^{15}\right)$, radio gymnastics $\left(\mathrm{Gao}^{16}\right)$, hopscotch $\left(\operatorname{Innerd}^{17}\right)$, playground games $\left(\right.$ Mackintosh $\left.{ }^{18}\right)$, different modes of active video games $\left(\right.$ Barkman $\left.^{19}\right)$, locomotor courses $\left(\operatorname{van} \operatorname{Loo}^{20}\right)$, and hand weights $\left(\mathrm{Lee}^{21}\right)$. Several studies in this issue include EE assessment of sedentary activities. These activities, which are of increasing public health interest, represent many of the activities performed by today's youth. For example, Honas et $\mathrm{al}^{22}$ evaluate EE during normal and active classroom instruction while others consider separate individual sedentary tasks, such as playing board games (Sasaki $\left.{ }^{11}\right)$, watching 
movies or television (Puyau ${ }^{8}$; Schuna ${ }^{12}$ ), drawing (Innerd $\left.{ }^{17}\right)$, reading $\left(\mathrm{Lee}^{21}\right)$, and playing a handheld e-game (van $\left.\mathrm{Loo}^{20}\right)$.

\section{Summary}

This supplemental issue contributes to the further development of the youth compendium and also highlights specific research needs for the future. In doing so, it points to 2 lessons. First, significant and important data are available in unpublished laboratory notebooks. Future efforts to compile physiological data could benefit by seeking out a journal that is willing to publish a supplement, and then advertising an opportunity for researchers to publish their data as an incentive. Second, despite obtaining new estimates of $\mathrm{EE}$ for diverse, understudied activities, further research is needed to expand and inform the youth compendium. In particular, a focus on measuring activities across several ages is important, due to the known variation in EE that occurs with age. Rigorous methodology is needed in future research to ensure comparability of data and accurate assessment, as is detailed description of the activities performed. This supplemental issue contributes to the updated youth compendium, which will be an invaluable tool for public health in terms of policy making and interventions to improve health and wellness of youth.

\section{Acknowledgments}

The authors wish to acknowledge the assistance of the National Cancer Institute (NCI), NCCOR, and the Centers for Disease Control and Prevention (CDC) for their support in facilitating the initial workshop, the development of a cohesive working group, and continued endeavors to improve the Youth Compendium of Physical Activity. The Working Group on Youth Energy Expenditure consists of Barbara Ainsworth, PhD, MPH (Arizona State University); David Bassett, PhD (University of Tennessee); David Berrigan, PhD (NCI); Nancy Butte, PhD (Baylor College of Medicine); Scott Crouter, PhD (University of Tennessee); Janet Fulton, PhD (CDC); Stephen Herrmann, PhD (Sanford Health/Research); Kate Ridley, PhD (Flinders University, Australia); Robert McMurray, PhD (University of North Carolina); Karin Pfeiffer, PhD (Michigan State University); Stewart Trost, $\mathrm{PhD}$ (Queensland University of Technology); and Kathleen Watson, $\mathrm{PhD}$ (CDC). We also wish to acknowledge the valuable contributions of those who attended the initial Youth Energy Expenditure Workshop: Bridget Borgogna (CDC); David Brown, PhD (CDC); Susan Carlson, $\mathrm{PhD}$ (CDC); Dianna Carroll, PhD (CDC); Kong Chen, PhD (NIDDK); Joan Dorn, PhD (CDC); Ginny Frederick, MS (CDC Foundation); Deb Galuska, PhD (CDC); Carmen Harris, MPH (CDC); Kristin lssacs, PhD (US Environmental Protection Agency); Sarah Lee, $\mathrm{PhD}$ (CDC); Robert Malina, PhD (Tarleton State University); Mindy Millard-Stafford, PhD (Georgia Institute of Technology); Don Morgan, PhD (Middle Tennessee State University); Chantelle Owens, MS (CDC); Prabasaj Paul, PhD (CDC); Russell R. Pate (University of South Carolina); Anne Rodgers (Science Writer); Tom Rowland, MD (Baystate Children's Hospital); MinKyoung Song, $\mathrm{PhD}$ (CDC); Andrea Torres, MPH (CDC).

\section{References}

1. Ainsworth BE, Haskell WL, Leon AS, Jacobs DR, Montoye HJ, Sallis JF, Paffenbarger RS. Compendium of physical activities: classification of energy costs of human physical activities. Med Sci Sports Exerc. 1993;25(1):71-80. PubMed

2. Harrell JS, McMurray RG, Baggett CD, Pennell ML, Pearce PF, Bangdiwala SI. Energy costs of physical activities in children and adolescents. Med Sci Sports Exerc. 2005;37(2):329-336. PubMed

3. Rowland TW. Children's Exercise Physiology. Champaign, IL: Human Kinetics; 2005.

4. Ridley K, Ainsworth BE, Olds TS. Development of a compendium of energy expenditures for youth. Int J Behav Nutr Phys Act. 2008;5:45. PubMed

5. McMurray RG, Butte NF, Crouter SE, etc. Exploring metrics to express energy expenditure of physical activity in youth. PLoS One. 2015;10(6):e0130869. PubMed

6. Byun W, Barry A, Lee J-M. Energy Expenditure of Daily Living Activities in 3- to 6-Year-Old Children. J Phys Act Health. 2016;13(Suppl 1):S3-S6.

7. Großek A, van Loo C, Peoples GE, Hagenbuchner M, Jones R, Cliff DP. Energy Cost of Physical Activities and Sedentary Behaviors in Young Children. J Phys Act Health. 2016;13(Suppl 1):S7-S10.

8. Puyau MR, Adolph AL, Liu Y, Wilson TA, Zakeri IF, Butte NF. Energy Cost of Activities in Preschool-Aged Children. J Phys Act Health. 2016;13(Suppl 1):S11-S16.

9. Lau M, Wang L, Acra S, Buchowski MS. Energy Expenditure of Common Sedentary Activities in Youth. J Phys Act Health. 2016;13(Suppl 1):S17-S20.

10. Ondrak KS, McMurray RG. Comparison of Energy Expenditure of Youth Playing Tennis During Practice and Match Settings. J Phys Act Health. 2016;13(Suppl 1):S21-S23.

11. Sasaki JE, Howe C, John D, et al. Energy Expenditure for 70 Activities in Children and Adolescents. J Phys Act Health. 2016;13(Suppl 1):S24-S28.

12. Schuna Jr JM, Barreria TV, Hsia DS, Johnson WD, Tudor-Locke C. Youth Energy Expenditure During Common Free-Living Activities and Treadmill Walking. J Phys Act Health. 2016;13(Suppl 1):S29-S34.

13. Trost SG, Drovandi CC, Pfeiffer K. Developmental Trends in the Energy Cost of Physical Activities Performed by Youth. J Phys Act Health. 2016;13(Suppl 1):S35-S40.

14. Ridley K, Olds T. The Energy Cost of Household Chores, Rollerblading, and Riding Scooters in 9- to 14-Year-Old Children. J Phys Act Health. 2016;13(Suppl 1):S75-S77.

15. Clevenger KA, Aubrey AJ, Moore RW, et al. Energy Cost of Children's Structured and Unstructured Games. J Phys Act Health. 2016;13(Suppl 1):S44-S47.

16. Gao Y, Sun H, Zhuang J, et al. Metabolic Equivalents of Selected Sedentary and Physical Activities in Chinese Youth. J Phys Act Health. 2016;13(Suppl 1):S48-S52.

17. Innerd AL, Azevedo LB. The Energy Expenditure of Free-Living Physical Activities in Primary Schoolchildren. J Phys Act Health. 2016;13(Suppl 1):S57-S61.

18. Mackintosh KA, Ridley K, Stratton G, Ridgers ND. Energy Cost of Free-Play Activities in 10- to 11-Year-Old Children. J Phys Act Health. 2016;13(Suppl 1):S71-S74.

19. Barkman J, Pfeiffer K, Diltz A, Peng W. Examining Energy Expenditure in Youth Using XBOX Kinect: Differences by Player Mode. $J$ Phys Act Health. 2016;13(Suppl 1):S41-S43.

20. van Loo CMT, Okely AD, Batterham M, et al. Predictive Validity of a Thigh-Worn Accelerometer METs Algorithm in 5- to 12-Year-old Children. J Phys Act Health. 2016;13(Suppl 1):S78-S83.

21. Lee JM, Saint-Maurice PF, Kim Y, Gaesser GA, Welk G. Activity Energy Expenditure in Youth: Sex, Age, and Body Size Patterns. J Phys Act Health. 2016;13(Suppl 1):S62-S70.

22. Honas JJ, Willis EA, Herrmann SD, et al. Energy Expenditure and Intensity of Classroom Physical Activity in Elementary School Children. J Phys Act Health. 2016;13(Suppl 1):S53-S56. 